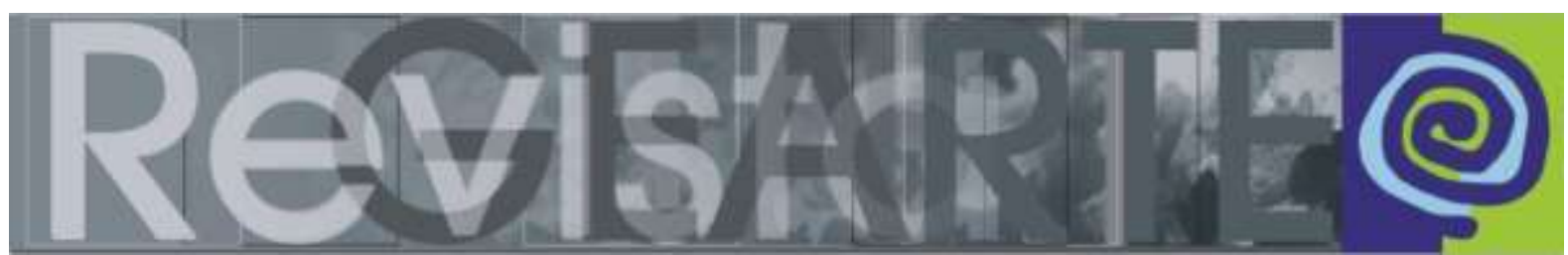

ISSN 2357-9854

\title{
Tanto vilão quanto herói: a estética do novo protagonista dos contos de fadas
}

\author{
Ana Mery Sehbe De Carli (UCS - Brasil) \\ Karem Roberta Sartor dos Santos (Pesquisadora independente - Brasil)
}

\begin{abstract}
RESUMO
A partir da observação de padrões culturais e comportamentos sociais da modernidade e da pósmodernidade, o conto de fadas A Bela Adormecida, em suas versões para Disney (EUA-1959 e EUA2014), é usado como objeto de estudo para constatação das polarizações entre o bem e o mal, presentes em representações até a primeira metade do século XX e o seu lento abandono, chegando à personagem Malévola, heroína e vilã ao mesmo tempo, caracterizando os humores fluídos do início do século XXI. Fundamentado em autores como Santaella, Maffesoli, Camargo, Corso e Corso, Calabrese e Eco o artigo trabalha na significação de produtos culturais do imaginário que facilitam a compreensão de paradigmas que se esgotam, dando lugar para novas formas de pensar e representar. PALAVRAS-CHAVE
\end{abstract}

Contos de fadas. Cinema. Estética. Cultura pós-moderna. Neobarroco.

\section{ABSTRACT}

Having as a starting point the observation of cultural patterns and social behaviour in Modern and Postmodern times the tale "Sleeping Beauty", in its Disney versions (USA-1959 and USA-2014), is used as a study object for the recognition of polarizations between evil and good. This binary relation is present in representations up until the first half of the 20th century, and their slow let down converging to the character "Maleficent", hero and villain at the same time, characterizing the fluid humours of the beginning of the 21st century. Based on authors such as Santaella, Maffesoli, Camargo, Corso and Corso, Calabrese and Eco the article works in the cultural imaginary products signification that facilitate the understanding of paradigms that run out, giving way to new ways of thinking and acting.

\section{KEYWORDS}

Fairy tales. Cinema. Aesthetics. Post-modern culture. Neo-baroque.

\section{Os estereótipos dos contos de fadas}

\subsection{Conceitos e autores}

O presente trabalho pretende abordar os padrões estéticos preconcebidos e impostos pela sociedade, em determinado tempo e espaço, que aparecem nas mais diversas formas de manifestações culturais. Santaella (2003) analisando os vários sentidos de cultura, segundo óticas das diversas ciências, diz que para a antropologia cultural, a cultura aparece como fenômeno regional. Assim, os elementos culturais, em qualquer tempo, "apresentam uma distribuição geográfica”. Essa distribuição por 
localidade define certos costumes e comportamentos; define as artes, as religiões, as crenças e as lendas como pertencentes às regiões em que elas existem.

Vale notar que os hábitos sociais de uma região podem ser absorvidos por outras regiões. Na verdade existe um trânsito, o que prova que nenhuma cultura foi ou é absolutamente autóctone. Morace (2007) diz que o desenvolvimento supremo da escultura grega se deu quando ela foi fecundada por certos estímulos vindos de outras culturas também tradicionais. A ideia dos outros quando aprovada tende a ser absorvida e misturada com a própria.

Santaella (2003) diz ainda que a cultura "envolve a repetição de comportamentos aprovados pelo grupo, de modo que ela tem uma forma e estrutura reconhecível" e tende seguir um padrão. Se as pessoas se acomodam ao padrão, a cultura permanece estável, mas isso não é uma regra. A própria mistura entre culturas provoca mudanças, que muitas vezes podem ser drásticas. Além da padronização de determinado grupo, e da permeabilidade potencial entre eles, existe subjacente a todas as culturas, padrões gerais ou universais que se expressam em categorias, tais como atividade econômica, arte, filosofia, religião e linguagem.

Considerados esses apontamentos de Santaella podemos dizer que alguns padrões gerais da cultura fecundaram profundamente no desenvolvimento das sociedades ocidentais, entre eles o pensamento racional moderno, creditado a Descartes (1596/1650) tido como "o fundador da filosofia moderna". O filósofo e matemático é um dos pensadores mais importantes e influentes da História do Pensamento Ocidental. Os pressupostos de Descartes revelam-se em sua célebre frase: cogito, ergo sum, ou "penso, logo existo", que sintetiza sua conclusão de que o pensamento é uma realidade em si mesmo, uma substância, distinta e diferente da matéria. Segundo o filósofo somos formados pela junção de duas substâncias distintas: uma substância pensante, o "res pensante", e uma substância material, o corpo, "res extensa". Esse fundamento dá origem ao dualismo cartesiano, que admite a existência de duas realidades em oposição: alma (res cogitans) e corpo (res extensa). A independência entre alma e corpo conduzirá a uma nova separação: sujeito e objeto (DE CARLI, 2009). O dualismo cartesiano pode ser considerado um padrão geral da filosofia que acompanha há mais de três séculos e meio a cultura 
ocidental. Daí se proliferam as dicotomias do pensamento racional moderno adepto a separações, oposições, como: corpo e espírito, razão e emoção, sujeito e objeto, bom e mau, bonito ou feio, conforme ou disforme, repulsivo ou atraente, sagrado ou profano e mais uma infinidade de oposições duais.

$\mathrm{Na}$ retrospectiva pode-se assumir o pensamento moderno como racional, objetivo, no qual os juízos de valor e a natureza das coisas são analisadas sob uma ótica dual. O intermédio nessas concepções dualistas nem é considerado, mas tem se mostrado muito presente nos conceitos de pensadores da pós-modernidade ${ }^{1}$.

Maffesoli (2004) contribui com importantes observações sobre padrões culturais, que ele denomina de "substratos da cultura que nos modela". Para o sociólogo esses substratos, de quando em quando, se saturam, perdem sua evidência para entrar progressivamente dentro de outro tipo de paradigma. As importantes mudanças de valores que assolaram as sociedades ocidentais a partir do agitado ano de 1968 vão caracterizar as facetas da cultura pós-moderna relevantes para esta reflexão: a primeira refere-se ao enfraquecimento das grandes instituições sociais que regiam a sociedade do século XIX, como a família, a universidade, os princípios civilizatórios, a igreja católica, etc. Aos poucos essas instituições se tornaram porosas e foram "devoradas" por muitas tribos ou inúmeros microgrupos. Da mesma forma as grandes ideias, as grandes narrativas de referência universal saturaram, cada uma a seu tempo, e passa-se a um cenário de múltiplas e pequenas histórias, diversas ideologias como uma forma de "babelização do pensamento". Os valores, antes absolutos, vêm cedendo espaço às considerações circunstanciais. O trânsito, a circunstância, a fluidez são parte do que se vê em inúmeras situações; há um nomadismo ideológico, profissional, afetivo. Nas palavras de Maffesoli vivemos, na pós-modernidade, um momento cultural em que prevalece valores politeístas:

À multiplicidade dos deuses corresponde a multiplicidade da pessoa. [...] $\mathrm{Na}$ verdade, segundo as necessidades específicas, há circulação de um deus para outro, da mesma forma como haverá variação permanente entre os diversos papéis que a própria pessoa é levada a desempenhar. Para dizer numa palavra tudo, o turbilhão da Odisséia renasce cada vez que prevalecem os valores politeístas. Tratar-se-á do nomadismo profissional, afetivo ou

\footnotetext{
1 O início da pós-modernidade não tem uma data de consenso. Teixeira Coelho (1986) diz que pode ter aparecido em algum momento entre o final da Segunda Guerra e o final dos anos 1960, quando em todo o mundo são identificados os movimentos contra as "autoridades constituídas".
} 
ideológico, ou aquele, mais pessoal, entre as diversas facetas do eu [...]. (MAFFESOLI, 2001, p. 110).

O segundo traço da modernidade que se esgotou foi o princípio da individuação, ou seja, a luta para a constituição do individuo que dá lugar a outra coisa. Assiste-se agora à passagem da identidade para as identificações múltiplas (MAFFESOLI, 2004). As pessoas acreditam em várias teorias, seguem muitas crenças, misturam ideias que pareciam antagônicas. Na política atual, por exemplo, constata-se uma mistura de várias ideologias, um trânsito de conveniências entre os vários partidos. Na religião observa-se pessoas que se dizem católicas, mas também frequentam sessões espíritas. Fatos dessa natureza mostram o movediço pensamento contemporâneo.

Maffesoli afirma: "A vida errante é uma vida de identidades múltiplas e às vezes contraditórias. Identidades plurais podendo conviver seja ao mesmo tempo, seja, ao contrário, sucessivamente. Alguma coisa oscilante entre 'a mesmice de si e a alteridade de si'." (2001, p. 118). O ser humano encontra em si diversas personagens; assume muitos papéis que aparecem em diferentes situações de seu cotidiano. Não somos limitados a estar de acordo com uma determinada identidade. Somos muitos em um só.

O quadro abaixo, desenvolvido por Camargo (2011) e adaptado pelas autoras, pode mostrar de forma didática algumas mudanças de paradigma da modernidade para pós-modernidade que são esclarecedoras para referências deste trabalho.

Quadro 1 - Comparativo entre Modernidade e Pós-Modernidade

\begin{tabular}{|c|c|}
\hline $\begin{array}{l}\text { MODERNIDADE } \\
\text { Do século XVIII até } 1980\end{array}$ & $\begin{array}{l}\text { PÓS-MODERNIDADE } \\
\text { Após } 1980\end{array}$ \\
\hline $\begin{array}{l}\text { RACIONALISMO } \\
\text { Confiança no poder da razão para } \\
\text { distinguir entre aparência e realidade, } \\
\text { conhecimento e ilusão, verdade e } \\
\text { falsidade, bem e mal. }\end{array}$ & $\begin{array}{l}\text { ILUSÃO RACIONAL } \\
\text { As pretensões da razão para o } \\
\text { conhecimento da realidade esbarram na } \\
\text { mediação das linguagens e na oculta } \\
\text { intenção de dominação e controle. }\end{array}$ \\
\hline $\begin{array}{l}\text { IDEAIS DA REVOLUÇÃO FRANCESA } \\
\text { Crença na igualdade entre os homens, na } \\
\text { liberdade garantida pela razão e na } \\
\text { fraternidade dos povos, assim como na }\end{array}$ & $\begin{array}{l}\text { DIVERSIDADE } \\
\text { Relativiza a igualdade, condiciona o livre } \\
\text { arbítrio e entende a fraternidade como } \\
\text { respeito à diferença entre os indivíduos, }\end{array}$ \\
\hline
\end{tabular}




\begin{tabular}{lll}
\hline $\begin{array}{l}\text { esfera dos direitos civis (cidadania), dando } \\
\text { origem à ideologia dos movimentos sociais. }\end{array}$ & $\begin{array}{l}\text { concebendo a sociedade como uma teia } \\
\text { fragmentada de grupos diversificados. }\end{array}$ \\
\hline ESSÊNCIA & APARÊNCIA \\
$\begin{array}{ll}\text { Capacidade de conhecer a essência ou } \\
\text { estrutura interna dos seres, definindo as }\end{array}$ \\
$\begin{array}{l}\text { causas e condições pelas quais ésimento não se define pela distinção } \\
\text { determinada sua identidade como coisa. }\end{array}$ & $\begin{array}{l}\text { aparência, mas pelos critérios de utilidade e } \\
\text { eficiência, sendo válido enquanto } \\
\text { transforma. }\end{array}$ \\
\end{tabular}

Fonte: Camargo, 2011, p. 13-14 (adaptado pelas autoras).

O autor ainda afirma que "a poeira levantada pela implosão do edifício da modernidade ainda nos cega para o novo quadro de referências que se forma à frente, na medida em que vamos penetrando a pós-modernidade" (2011, p. 12). Assim do racionalismo moderno, dos movimentos de classe e da preocupação com a essência das coisas, passamos para uma sociedade mediada por discursos que esmorecem os limites e as oposições radicais, aceitam a diversidade, trilham caminho de respeito às diferenças, sendo mais adeptos a mudanças circunstanciais dos seres e da existência.

Para afirmar as considerações desse primeiro item, que caracteriza mudanças de paradigmas culturais, inclui-se a fala de Maffesoli (2007), que considera que as mudanças são cíclicas e que as formas como elaboramos as representações sociais e os comportamentos voltam de tempos em tempos. Para esclarecer, o autor recorre a Sorokin, sociólogo americano, que indica que existem, empiricamente, dois tipos de conjuntos sociais: 1) os conjuntos sociais de preferência de tipo racionalista; 2) os conjuntos sociais de preferência de tipo sensualista. Os primeiros seriam regidos pela figura emblemática de Apolo, deus digno, discreto, límpido, equilibrado, expressão da moderação. E os segundos, de tipo sensualista, seriam regidos, por sua vez, por Dionísio, o deus grego da exuberância, da liberdade, da exaltação dos valores vitais, da embriaguez criativa; imagem da força instintiva e da natureza.

Essa metáfora de Sorokin para falar das mudanças culturais é emblemática e talvez possa ser aplicada não apenas para a mudança específica da modernidade para a pós-modernidade, mas para outras tantas mudanças que operam na cultura, modificando os padrões vigentes. 


\subsection{A coerência dos contos de fadas}

É importante as análises dos contos infantis, porque eles representam ideologias, verdades, ansiedades, receios, perigos que se pretende aproximar ou afastar de um determinado grupo e espaço cultural. Os contos, assim como outras representações culturais de ficção, apresentam personagens que caracterizam o bem e o mal com a pretensão de passar posições que afirmam valores que se quer resguardar. Bettelheim (2002, p. 92) enfatiza que "o conto de fadas nos ajuda a entendermo-nos melhor, já que na estória os dois lados de nossa ambivalência são isolados e projetados ....".

A partir do início do século $X X$ os contos de fadas passam a ter intenções pedagógicas e mercadológicas, provocando a definição de um público alvo (CORSO; CORSO, 2006). As histórias passam a designar a faixa etária do público e se tornam uma ferramenta educacional, distinguindo malvados e benfeitores, princesas e seres mágicos; bandidos e mocinhos; fadas e bruxas. Diferente da estética barroca do século XVII, em que a contação de histórias era feita para adultos e crianças sem distinção nenhuma, com o intuito de apresentar os perigos presentes na época. Os contos serviam como forma de alerta para pessoas se precaverem de situações ameaçadoras.

Nos contos de fadas há clichês do estereótipo do vilão e do estereótipo do herói que podem ser facilmente identificados pela personalidade, expressões faciais, traços físicos, vestes, linguagem corporal e mais inúmeras articulações entre as linguagens sonoras, visuais e verbais, quando se trata da linguagem híbrida do cinema. Mas a primeira impressão que se tem parte dos sentidos, implicando a produção de sons, imagens, texturas, sabores e odores. Inicialmente as cores, as formas, os sons, a expressão ou vestes sinalizam a conduta de uma determinada personagem. As diferenças demonstradas em prol da afirmação das dualidades - bom/mau, bonito/feio - são marcas relevantes na constituição da personagem.

As tonalidades das roupas usadas pelos intérpretes das histórias passam impressões e sensações e estabelecem relações simbólicas de significado numa determinada cultura. Pedrosa (1982) explica que o vermelho refere-se ao afeto e suas 
manifestações, que podem ser suaves, mas também violentas e explosivas. Um amor passional, uma paixão, que pode chegar à violência, remete também ao vermelho, enquanto o azul e os violáceos falam de movimento emocional introspectivo. Picasso, na fase azul, nos remete à tristeza, à solidão. Nos desenhos animados essas qualidades que exploram a sensorialidade visual, sonora e tátil assumem símbolos de consenso. Assim, o vilão usa cores mais escuras, como preto, vermelho sangue, roxo, terra, cinza chumbo; o herói aparece com o azul-celeste, verde-água, branco, baunilha e na maioria das vezes é bonito, pele e cabelo claros, olhos azuis, feições arredondadas, olhar dócil e bom coração, enquanto seu oposto, o vilão, tem feições tensas, olhos escuros, ardilosos, nariz aquilino, maçãs do rosto salientes, traços angulosos, é feio e até deformado. Esse padrão aparece em diversos filmes, novelas, desenhos infantis.

Pesquisando sobre questões relacionadas ao perfil de vilões e heróis, salientamos a explicação de Calabrese (1998) sobre os juízos de valor, quando se compara o modelo clássico e o modelo neobarroco. Depois de estudar as colocações de Sorokin podemos também assumir que o modelo clássico é apolíneo e o modelo neobarroco é dionisíaco. O quadro dos juízos de valor, mostra como eles se interrelacionar numa representação clássica ou apolínea. Neste contexto os valores clássicos reportam-se à arte da Grécia e Roma antigas ou as obras que incorporam as qualidades inerentes àquelas de harmonia, ordem, simetria e equilíbrio (MYERS, 1971).

Quadro 2 - Homologações entre as categorias de valor nas sociedade muito normalizadas

\begin{tabular}{|cccc|}
\hline CATEGORIA & JUÍzo SOBRE & VALOR POSITIVO & VALOR NEGATIVO \\
\hline Morfológica & Forma & Conforme & Disforme \\
\hline Ética & Moral & Bom & Mau \\
\hline Estética & Gosto & Belo & Feio \\
\hline Tímica & Paixão & Eufórico & Disfórico \\
\hline
\end{tabular}

Fonte: Calabrese, 1998, p. 107.

As culturas que levam como exemplo os modelos clássicos tomam para si valores que são possíveis exemplificar através de quatro categorias, sendo elas: 
morfológica, ética, estética e tímica. As categorias ética e estética "contêm um juízo que implica em louvor e reprovação". As outras duas, morfológica e tímica, "são categorias constatativas, no sentido de que dão um juízo de realidade" (CALABRESE, 1998, p. 107).

Na representação clássica é destaque a harmonia entre as categorizações, assim o mocinho, personagem do bem, será conforme, bom, belo e eufórico, e o bandido, personagem do mal, será: disforme, mau, feio e disfórico. Os conjuntos são homogêneos e dualistas; é o que vemos nos contos de fadas tradicionais com intenções pedagógicas.

O neobarroco (CALABRESE, 1998) do século $X X$, que avança na contemporaneidade, faz referência direta ao estilo barroco do século XVII, que na fusão da arquitetura, pintura e escultura buscava provocar uma reação emocional no espectador e envolvê-lo espiritualmente. No alto barroco, o estilo alcançou extravagância de forma e de cor e foi impregnado de uma nova alegria profana.

Nas produções culturais das últimas décadas, que o autor denomina neobarrocas, se sobressai o apreço que temos hoje pelos monstros: "o monstro serve para representar não só o sobrenatural ou o fantástico, como, e acima de tudo, o maravilhoso, que depende da raridade e casualidade da sua gênese na natureza e da oculta teleologia da sua forma" (CALABRESE, 1998, p. 106). Na história da feiúra Eco destaca:

\begin{abstract}
No curso dos séculos, reconheceu-se a existências de coisas belas e agradáveis e de coisas ou fenômenos terríveis, apavorantes e dolorosos com frequência, louva-se a arte por imitar ou representar de modo belo ou feio, o informe, o terrível, os monstros ou o diabo, a morte ou uma tempestade. Em sua Poética, Aristóteles explica justamente que a tragédia, ao representar eventos tremendos deve produzir no espírito do espectador piedade e terror (...) No século XVII alguns pintores foram apreciados por suas representações de seres feios, desagradáveis, estropiados e mancos, ou de céus nebulosos e tempestuosos. (ECO, 2012, p. 281).
\end{abstract}

A composição clássica harmônica está perdendo espaço para composições mais complexas. A fluidez, o movediço, a mistura, a circunstância são palavras que adjetivam a realidade social atual, na qual a essência se dissolve nas circunstâncias, 
em que rótulos ou estigmas culturais que circunscrevem e limitam os movimentos e as escolhas do indivíduo são progressivamente descartados.

Comparando duas versões do conto de fadas $A$ Bela Adormecida produzidas pelo Estúdio Disney - a primeira em 1959, que leva o titulo original, e a segunda, Malévola, de 2014 - pode-se apreciar essa mudança de paradigmas que tão bem caracteriza a sintonia do conto de fadas com os sintomas sociais do seu tempo.

Por outro lado, as oposições que aparecem em boa parte dos contos de fadas podem ser de certa maneira um facilitador para se fazer compreender devagar e mais didaticamente situações que acontecem fora dos contos de fadas. Assim como a ambivalência torna confusa a idealização de bem e de mal para uma criança, a leitura e a contação de histórias amenizam o impacto agressivo da realidade.

\section{Versões da Bela Adormecida - Disney Studio}

Neste item são abordadas as versões da história adaptadas para o cinema através de produções do Disney Studio.

\subsection{A Bela Adormecida (1959)}

\section{Ficha técnica}

- Título original: Sleeping Beauty, A Bela Adormecida, 1959 (EUA), baseado no conto de fadas de Charles Perrault

- Gênero: Animação, Fantasia, Infantil

- Direção: Clyde Geronimi

- Produção: Walt Disney Pictures

- Trilha Sonora: Robert O. Cook

- Premiação: OSCAR de Melhor Trilha Sonora (1960); GRAMMY de Melhor Álbum - Cinema/TV (1959).

\section{Sinopse}

O filme relata a comemoração do nascimento da princesa Aurora, filha do rei Estevão e da rainha Leah. A menina ganha presentes mágicos das três fadas: Fauna, Flora e Primavera. Em meio aos festejos surge Malévola bastante perplexa por não ter sido convidada para o evento. Ela amaldiçoa Aurora, dizendo que ao completar 16 anos espetará o dedo no fuso de uma roca e morrerá. As três fadas conseguem 
descobrir como quebrar o feitiço. Somente um verdadeiro beijo de amor poderia despertar a princesa. Enquanto o reino dorme em sono profundo, o príncipe Filipe, grande amor de Aurora, agraciado pelas fadas com o escudo da virtude e a espada da verdade, enfrenta Malévola e finalmente a derrota. Por fim, ele quebra o feitiço, dando um verdadeiro beijo de amor em Aurora, e eles vivem felizes para sempre.

\section{Comentários}

Na sinopse do filme já é possível perceber características marcantes da cultura moderna em vários aspectos, entre eles: o dualismo cartesiano, mostrando a oposição entre o bem e o mal. Malévola é uma bruxa má que tem que ser vencida pelas boas fadas através do herói, o príncipe, e a recompensa é o amor e a felicidade para sempre. O gênero animação fantasia infantil engaja-se nas finalidades racionais, pois a partir do início do século XX "o cinema apresentava-se como um veículo de inscrição civilizatória muito apropriado, permitindo agregar entretenimento, pedagogia e informação" (DE CARLI, 2009, p. 57), ou seja, um manancial de modelos certos ou errados, excludentes, somados à "racionalidade instrumental", típica também da modernidade que dita que "toda a coisa vale somente na medida em que serve para uma finalidade ou mostra sua utensilidade" (MAFFESOLI, 1997).

O casamento é tratado como a grande realização da mulher, e os papéis do feminino e do masculino pouco avançaram em relação aos romances educativos de Rousseau (1712-1778). Ao final da cena do baile fica evidente a visão do final feliz para sempre, do casamento ideal para a vida.

Os looks do "bem" são caracterizados nas linhas, formas, cores, singularidades e referenciais reconhecidos. A princesa Aurora (Figura 2) é desenhada em linhas suaves e arredondadas, cabelos ondulados; as cores do seu figurino são azul, rosa, bege e branco; os passarinhos e as flores estão sempre à sua volta. A sua imagem de referência é a atriz Audrey Hepburn (Figura 1), considerada a princesa de Hollywood, a "bonequinha de luxo", frágil, meiga e de bom caráter, que merece um príncipe encantado. As fadas que cuidam da princesa Aurora são redondinhas; suas fisionomias são dóceis e as vestes são claras; seus sobrevoos deixam um rastro de estrelinhas luminosas. 
Figura 1 - Audrey Hepburn como Bonequinha de Luxo (Breakfast at Tiffany's), EUA, 1961

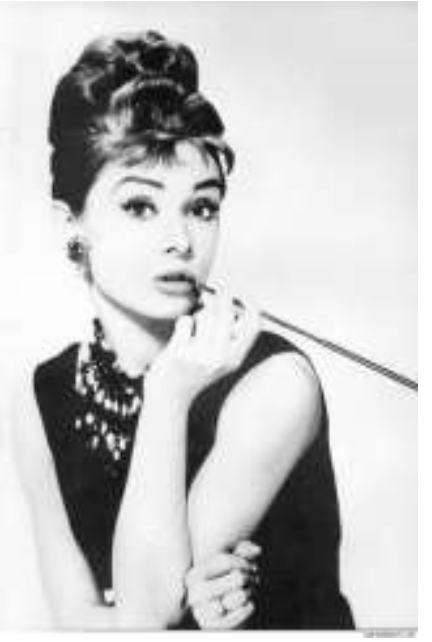

Fonte:

http://www.imdb.com/name/nm0000030/.
Figura 2 - Aurora em A Bela Adormecida, EUA, 1959

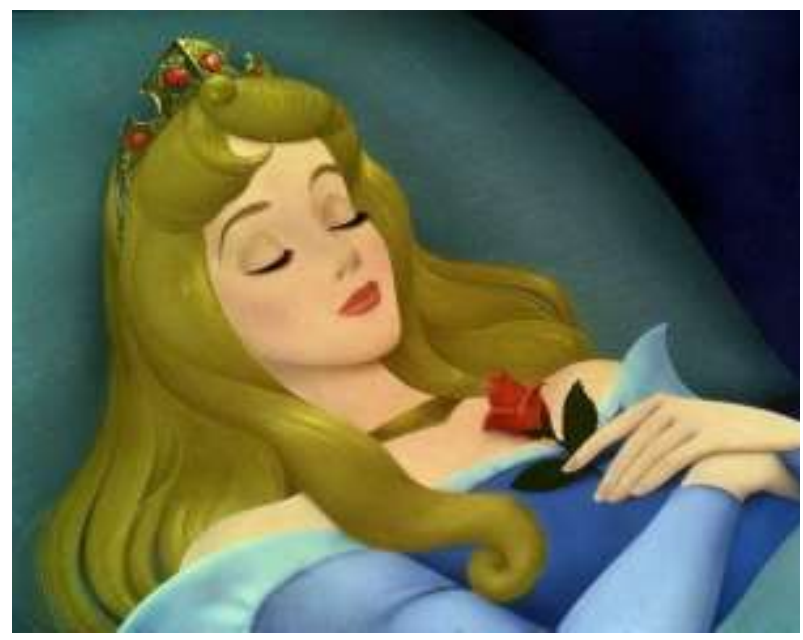

Fonte: http://disney.wikia.com/wiki/ Sleeping_Beauty.

Malévola (Figura 4) é má, desenhada em linhas pontiagudas; a pele é esverdeada, o rosto é alongado, o queixo proeminente; tem chifres como os demônios e sua roupa é preta com detalhes em roxo. A gola pontiaguda e a ampla capa conferem um poder obscuro, lembrando o verticalismo gótico e as sombras do Expressionismo Alemão em personagens sombrios como Nosferatu (Figura 3).

Os artistas expressionistas, muitos dos quais trabalhavam na Alemanha, queriam criar uma arte que confrontasse o expectador com uma visão mais direta e pessoal de seu estado de espírito. O expressionismo era uma forma de arte representativa que incluía certos elementos essenciais, distorção linear, reavaliação do conceito de beleza artística, simplificação radical de detalhes e cores intensas. (...) Os expressionistas alcançaram um elevado senso de urgência por meio do uso de cores não naturais e formas exageradas e alongadas. (FARTHING, 2010).

O entorno da Malévola é assustador: raios, trovões, espinhos e seu fiel companheiro, o corvo. Na produção de 1959 fica escancarada a dicotomia entre o bem e o mal. 
Figura 3 - Cena de Nosferatu, Alemanha, 1922

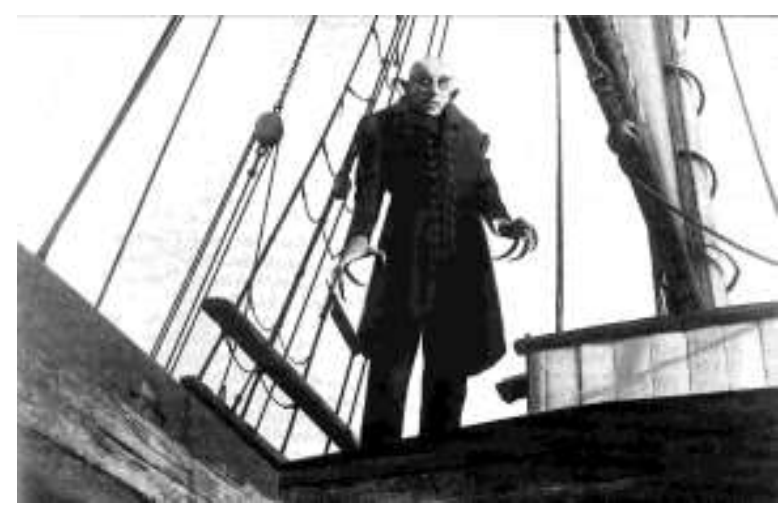

Fonte:

www.cinefrance.com.br/_images/filmes/nosferat u1.jpeg.
Figura 4 - Malévola em A Bela Adormecida, EUA, 1959

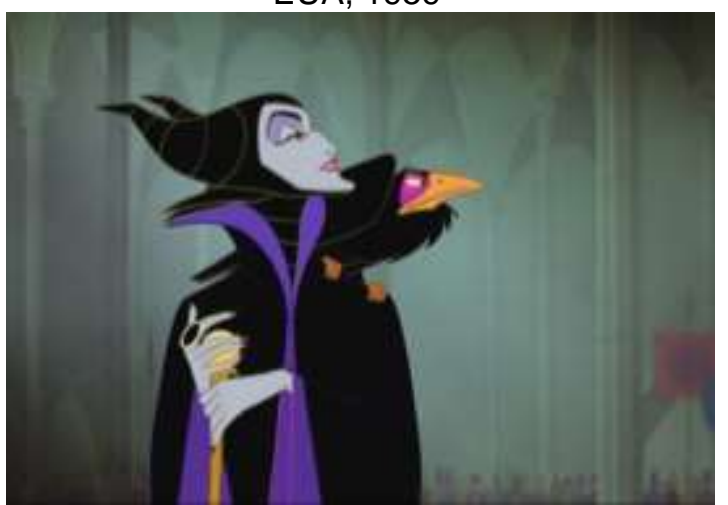

Fonte: http://static2.hypable.com/wpcontent/gallery/maleficent-sleeping-beautychanges/maleficent-sleeping-beautydifferences-changes-maleficent.jpg.

Ao observar a imagem do vampiro na Figura 3 podemos relacionar alguns aspectos similares aos da personagem Malévola. As mãos são um bom exemplo: com dedos finos e compridos, lembrando garras, são características bastante marcantes. Ambos, Vampiro e Malévola, são considerados disformes, maus, feios e disfóricos, de acordo com o quadro dos juízos de valor de Calabrese.

\subsection{Malévola (2014)}

\section{Ficha técnica}

- Gênero: Fantasia

- Direção: Robert Stromberg

- Elenco: Angelina Jolie

- Produção: Don Hahn, Joe Roth, Richard D. Zanuck

- Produção: Walt Disney Pictures

- Fotografia: Dean Semler

\section{Sinopse}

A história da Bela Adormecida contada pela perspectiva da vilã Malévola traz a trama de uma jovem ingênua e bela que vive em um reino pacífico localizado em uma floresta. O exército do reino vizinho surge e ameaça a harmonia da região. Malévola surge ferozmente para proteger seu povo, mas acaba sendo vítima de uma traição. Esse fato faz com que seu coração endureça; ela e sua floresta que outrora era repleta de harmonia se veem sedentas por vingança. Malévola enfrenta o rei dos humanos 
em uma grande batalha e amaldiçoa sua filha recém-nascida, Aurora, com mesma maldição do conto tradicional. Conforme a menina cresce, Malévola percebe que Aurora é a peça essencial para restabelecer a paz no reino e sua própria paz interior.

\section{Comentários}

Atualmente, em representações culturais como novelas, romances, peças de teatro e filmes se vê a questão da ambivalência das personagens. A aparição do vilão, com flashes de herói, é cada vez maior nas histórias. Ele é o tipo de personagem que por vezes age fazendo justiça com as próprias mãos e/ou realiza atos que heróis fariam, mas por causas egoístas; e ainda é um vilão, mas defende uma boa causa. Enfim, os julgamentos de valor ficam mais complexos.

Um exemplo de nova produção mostrando outra perspectiva em relação aos contos de fadas e mudando da animação para personagens de carne e osso é Malévola. É uma produção da Disney, referente ao antigo conto de Perrault, Basile e os irmãos Grimm. O título do filme já evidencia o ponto de vista da até então vilã da história. De Carli sinaliza que "na fragilização das fronteiras dicotômicas da cultura moderna surgem histórias envolventes, no imaginário do cinema, que avançam para uma estética pós-moderna, neobarroca ou líquida” (2012, p. 1194).

A partir de produções contemporâneas é possível perceber que o papel do vilão muda. A trama contada pelo vilão mostra lados desconhecidos da sua história, que despertam sentimentos dúbios, complexos em relação a todo o mal que eles representavam. Um exemplo típico é em Guerra das Estrelas IV, quando Darth Vader, pai de Luke Skywalker, narra seu trágico romance em que se vê obrigado a renunciar o bem pelas seduções do mal. Malévola revolta-se com a traição de um grande amor na adolescência e assim justifica sua vingança. Os dois lados da personagem estão presentes, sua fúria e sua bondade. A atriz Angelina Jolie encarna Malévola, auxiliando a criar um paradoxo entre ficção e realidade, pois ela representa um padrão de beleza de consenso no mundo ocidental e é reconhecida por sua empatia com o sofrimento dos oprimidos. 
Figura 5 - Cartaz oficial do filme Malévola no

Brasil

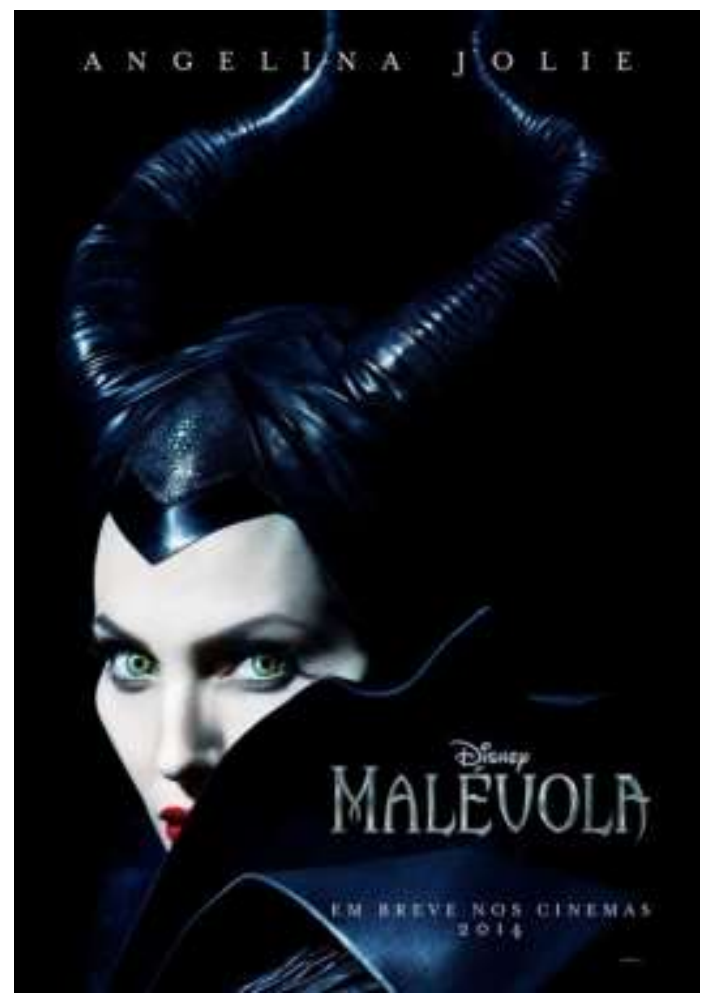

Fonte:

http://br.web.img2.acsta.net/pictures/210/571

/21057123_20131112192017072.jpg.

É possível ver similaridades entre Malévola e outro mito muito conhecido na religiosidade católica apostólica romana: Lúcifer, o anjo caído. Já as novas produções têm um teor atraente e humano, mostrando perfis de personagens menos radicais, nem tão bondosos e nem tão malvados, nem tanto ao céu, nem tanto à terra, misturando características que antes eram mostradas de forma racionalmente polarizadas (Figuras 6 e 7 ). 
Figura 6 - Angelina Jolie como Malévola

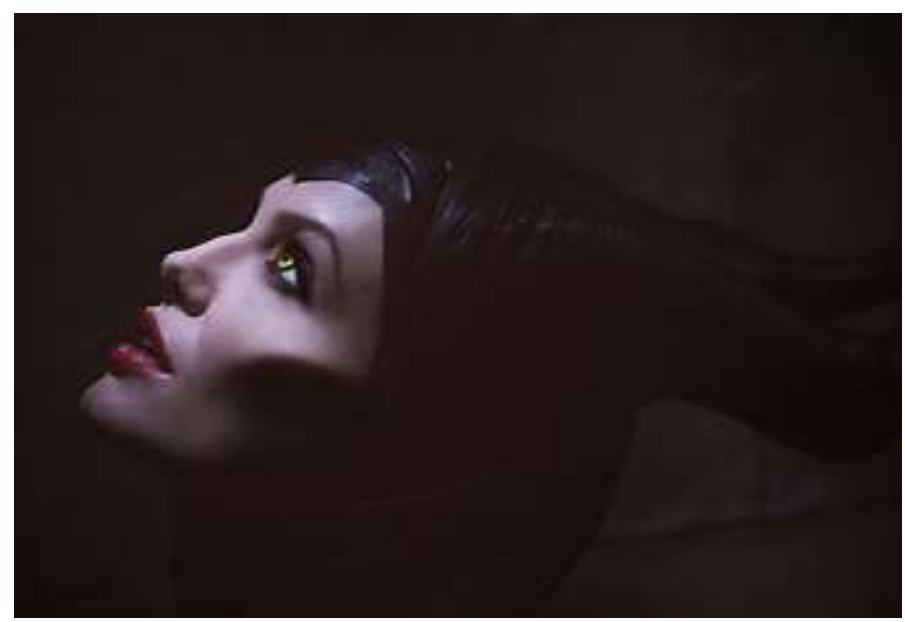

Fonte: http://cdn.screenrant.com/wpcontent/uploads/angelina-jolie-maleficent.jpg .
Figura 7 - Angelina Jolie como Malévola

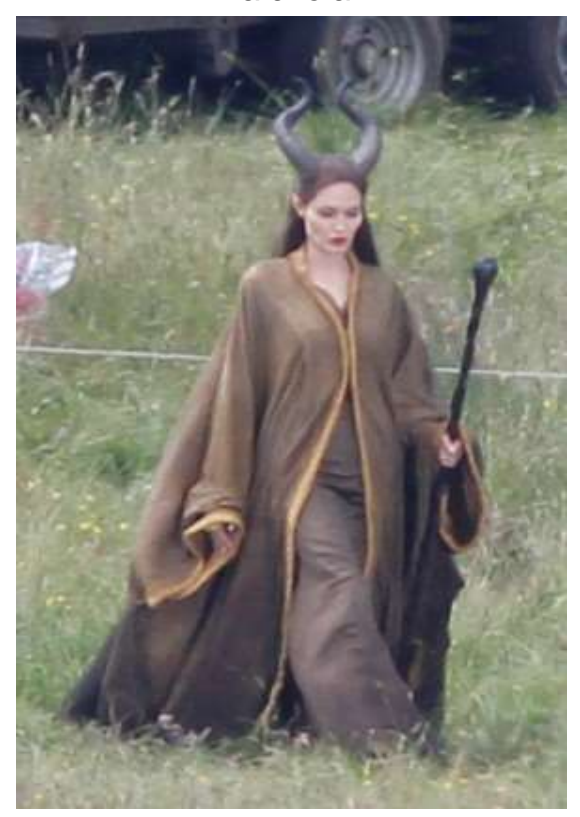

Fonte:

http://www.eonline.com/eol_imag es/Entire_Site/2012520/reg_634.

AngelinaJolie.jc.062012.jpeg.

A própria Angelina Jolie, atriz que interpreta Malévola, conta que quando era criança tinha medo da personagem, mas de alguma maneira ficava hipnotizada ao vêla. O que mais Ihe chamava a atenção era sua "elegância e crueldade deliciosa".

Jolie destaca que a Malévola, nesse filme, não funciona essencialmente como uma vilã, mas é alguém com muitas questões inacabadas. A atriz fala que Malévola é, na verdade, uma ótima pessoa, mas é imperfeita. Ela está longe da perfeição, mas ensina a ver o outro lado das coisas. O desafio do filme, contando a história reversa, é implicar com as verdades estabelecidas, é despertar o senso critico, é entender a diversidade e a complexidade das situações que não acatam simplificações dadas.

A respeito do figurino, Jolie diz que os chifres são os chifres e você não pode negá-los. Malévola precisa ter os chifres. O figurino é similar ao da animação de 1959, mas a personagem não. As roupas e a fisionomia de Malévola mudam conforme sua paixão, ora eufórica, ora disfórica. O mesmo acontece com seu reino. Antes do coração de Malévola ser tomado pelo sentimento de vingança as personagens são estranhas, feias, disformes, mas a bondade está no ar. Quando os sentimentos de 
vingança dominam, tudo é sombrio e assustador, os espinhos erguem a grande barreira entre o reino dos humanos e o reino de Malévola.

Malévola luta com poder e força sublimes até saciar sua sede de vingança. $\mathrm{Na}$ reviravolta do humor e da paixão ressurge a harmonia, e aqueles seres diferentes, feios, estranhos, disformes, gentis, bondosos, tudo misturado, voltam a reinar na terra de Malévola. E no próprio happy end do filme fica o dito: "No final, o meu reino não estava unido por um herói ou um vilão, como a lenda tinha previsto, mas por alguém que era ao mesmo tempo herói e vilão. E o seu nome era Malévola."

Assim as teorias abordadas neste artigo encontram ressonâncias em algumas histórias contemporâneas, nas quais se pode ver: a saturação do substrato cultural da modernidade; as classificações dualistas abrindo espaço para a complexidade; o desassossego na forma e estrutura da narrativa convencional; as representações visuais que embaralham as concepções tradicionais do nosso olhar; o comportamento fluído que contém, nas suas dobras, Apolos e Dionísios; as identidades múltiplas que o sujeito pode assumir nas contingências do cotidiano e ainda o aprendizado para conviver com a diversidade.

\section{Referências}

BARRA, Mário. "Ela é deliciosamente cruel", diz Angelina Jolie sobre "Malévola". Disponível em: $<$ http://cinema.uol.com.br/noticias/redacao/2013/08/10/ela-e-deliciosamente-cruel-diz-angelina-joliesobre-malevola.htm\#fotoNav=4> Acesso em: 5 out. 2013.

BAUMAN, Zygmunt. Vida líquida. Rio de Janeiro: Jorge Zahar, 2007.

BELA Adormecida, A. Direção: Clyde Geronimi. Walt Disney Studio. Los Angeles: 1959. 75 min. Disponível em: <https://www.youtube.com/watch?v=xoC1_hfWxD4> Acesso em:3 ago. 2013.

BETTELHEIM, Bruno. A psicanálise dos contos de fadas. São Paulo: Paz e Terra, 2002.

BRIDI, Natália. Maleficent. Disponível em: <http://omelete.uol.com.br/angelina-jolie/cinema/maleficentangelina-jolie-fala-sobre-filme-que-contara-ponto-de-vista-da-bruxa-de-bela-

adormecida/\#.Uljh3IBJMms> Acesso em: 5 out. 2013.

CALABRESE, Omar. A idade neobarroca. Lisboa: Edições 70, 1998.

CAMARGO, Marcos. A crise da representação moderna. Faculdade de Artes do Paraná: Biblioteca Online de Ciências da Comunicação, 2011. Disponível em <http://www.bocc.ubi.pt/pag/camargo-marcosa-crise-da-representacao-moderna.pdf> Acesso em: 10 out. 2013.

COELHO, José Teixeira. Moderno pós-moderno. Porto Alegre: L\&PM, 1986.

CORSO, Diana Lichtenstein; CORSO, Mário. Fadas no divã: psicanálise nas histórias infantis. Porto Alegre: Artemed, 2006. 
DE CARLI, Ana Mery. Corpos híbridos e contaminados: vampiros e lobisomens desafiando os rótulos. In: INTERNATIONAL FASHION AND DESIGN CONGRESS, 1., 2012, Guimarães. Anais... Guimarães: CIMODE, 2012. p. 1189-1196.

DE CARLI, Ana Mery. O corpo no cinema: variações do feminino. Caxias do Sul: Educs, 2009.

ECO, Umberto. História da beleza. Rio de Janeiro: Record, 2012.

ENCICLOPÉDIA As Belas Artes. Como apreciar arte. São Paulo. 1967, v. 10.

FARTHING, Stephen. Tudo sobre arte: os movimentos e as obras mais importantes de todos os tempos. Rio de Janeiro: Sextante, 2010.

LAUDENIR, Antonio. Angelina Jolie fala sobre seu personagem no filme Malévola. Disponível em: $<$ http://cinemacomrapadura.com.br/noticias/306650/angelina-jolie-fala-sobre-seu-personagem-no-

filme-malevola> Acesso em: 5 out. 2013.

MAFFESOLI, Michel. O tempo das tribos: o declínio do individualismo nas sociedades de massa. Rio de Janeiro: Forense Universitária, 2006.

MAFFESOLI, Michel. O conhecimento comum. Porto Alegre: Sulina, 2007.

MAFFESOLI, Michel. Perspectivas tribais ou a mudança do paradigma social. Revista Famecos: mídia, cultura e tecnologia, Porto Alegre, n. 23, p. 23-29, 2004.

MAFFESOLI, Michel. Sobre o nomadismo: vagabundagens pós-modernas. Rio de Janeiro: Record, 2001.

MALÉVOLA. Direção: Robert Stromberg. Produção: Don Hahn; Joe Roth; Richard D. Zanuck. EUA: The Walt Disney Studios, 2014.

MARTín, Carmen. Nova biografia mostra como Audrey Hepburn virou princesa de Hollywood. Disponível em: <http://www1.folha.uol.com.br/ilustrada/852013-nova-biografia-mostra-como-audreyhepburn-virou-princesa-de-hollywood.shtml> Acesso em: 11 out. 2013.

MORACE, Francesco. A globalização e o futuro brasileiro. In: Globalização da economia têxtil e de confecção brasileira. Rio de Janeiro: SENAI/CETIQT, 2007.

MYERS, Bernard. As belas-artes. Lisboa: Publicações e artes gráficas, SARL, 1971.

NOSFERATU. Direção: Friedrich Wilhelm Murnau. Produção: Albin Grau, Enrico Dieckmann. Alemanha: Prana Film, 1922.

PEDROSA, Israel. Da cor à cor inexistente. Rio de Janeiro: Leo Christiano, 1982.

SANTAELLA, Lucia. Culturas e artes do pós-humano: da cultura das mídias à cibercultura. São Paulo: Paulus, 2003.

SANTAELLA, Lucia. Semiótica aplicada. São Paulo: Cengage Learning, 2002.

SANTANA, Ana Lucia. Arquitetura gótica. Disponível em: <http://www.infoescola.com/arquitetura/ arquitetura-gotica/> Acesso em: 11 de out. 2013.

\section{Ana Mery Sehbe De Carli}

Professora e pesquisadora do Centro de Artes e Arquitetura da Universidade de Caxias do Sul. Doutora em Comunicação e Semiótica PUC/SP, com a pesquisa O corpo no cinema: variações do feminino, estudo do corpo, da moda e do comportamento através de filmes do circuito comercial. Mestre em Comunicação e Semiótica (PUC/SP e UCS). Coordena o Grupo de Pesquisa CNPq: Design, sustentabilidade e tecnologia. Recebeu Prêmio Economia Criativa, 2012, da SEC do MINC, com o projeto Moda no terceiro milênio: novos valores novas práticas. Autora dos livros: O sensacional da moda (2002); O corpo no cinema: variações do feminino (2009); Moda em Sintonia (2010); Moda sustentabilidade e emergências (2012).

E-mail: sdecarli@terra.com.br

Currículo: http://lattes.cnpq.br/3426240653398672 


\section{Karem Roberta Sartor dos Santos}

Possui Graduação em Licenciatura em Artes Visuais (2011) e Especialização em Artes Visuais pela Universidade de Caxias do Sul (2013). Formada no curso de Editor Gráfico pelo SENAC (2013). É graduanda em Design Gráfico (FTEC). Foi bolsista na Biblioteca da Universidade de Caxias do Sul/Campus 8; estagiou na Secretaria da Cultura de Caxias do Sul; ministrou oficinas de Produção e Teoria em Arte.

E-mail: karemrss@gmail.com

Currículo: http://lattes.cnpq.br/0306437720328014 